\title{
Length-Weight Relationships of Four Different Sea Cucumber Species in North-East Coastal Region of Sri Lanka
}

\author{
K. Veronika*, U. Edrisinghe ${ }^{1}$, K. Sivashanthini ${ }^{2}$ and A.R.S.B Athauda ${ }^{1}$ \\ Postgraduate Institute of Agriculture \\ University of Peradeniya \\ Sri Lanka
}

\begin{abstract}
A detailed investigation on length-weight relationship of four sea cucumber species, Holothuria spinifera, Bohadschia marmorata, Stichopus naso, and Holothuria atra found in the commercial catches of North-East coastal waters of Sri Lanka was conducted from May 2014 to September 2016. Minimum length and weight were recorded in $\underline{S}$. naso while maximum size was recorded by $\underline{B}$. marmorata. Length-weight relationship was carried out to investigate the correlation coefficient ( $r$ ), exponent " $b$ " value and condition factor $(K)$. Calculated length-weight relationships obtained for $\underline{H}$. spinifera, $\underline{B}$.

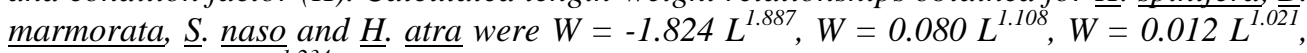
and $W=-0.110 L^{1.234}$, respectively. Correlation coefficient for length-weight relationship ranged from 0.696 to 0.774 and was significant at $P<0.01$ indicating good correlation between length and weight. The " $b$ " values of $\underline{H}$. spinifera (1.887), B. marmorata (1.108), S. $\underline{\text { naso }}(1.021)$ and $\underline{H}$. atra (1.223) were significantly different $(P<0.05)$ from the hypothetical value of 3 , showing a negative allometric growth pattern. The mean condition factor $(K)$ was

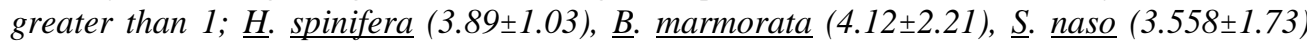
and $\underline{H}$. atra $(2.688 \pm 1.34)$ indicating the good nutritional condition in all four sea cucumbers species.
\end{abstract}

Keywords: Allometric growth, coastal waters, Holothuria spinifera, length-weight relationship

\section{INTRODUCTION}

There are 75 known species of sea-cucumbers found in inter-tidal areas of Sri Lanka (Clark and Rowe, 1971). Most of the sea-cucumber catch comes from North, East and North-west regions of Sri Lanka. At present around 25 sea-cucumber species have been identified, while 21 species are considered as commercially important (Dissanayake \& Stefanson, 2010). However, seven species of sea-cucumbers belonging to two families have been recorded from Point Pedro and Mullaitivu coastal waters in North-east region of Sri Lanka (Veronika et al., 2016; Veronika et al., 2017). Among them, Holothuria atra (Jaeger, 1833), Bohadschia marmorata (Jaeger, 1833), Stichopus naso (Samper, 1868) and Holothuria spinifera (Theel, 1886) have a higher demand than other species.

\footnotetext{
1 Department of Animal Science, Faculty of Agriculture, University of Peradeniya, Sri Lanka

2 Department of Fisheries, Faculty of Agriculture, University of Jaffna, Sri Lanka

* Corresponding author: kveronika.8@gmail.com
} 
Length-weight relationship is of great importance in fishery assessments of aquatic species (Garcia et. al., 1998; Haimovici and Velasco, 2000). It is essential to estimate the average weight at a given length group and also useful to convert growth-in-length data to growth-inweight in stock assessment models (Beyer, 1987). A detailed knowledge on ratio of the length to the weight for different stock species provides vital information in fisheries management. Furthermore, condition factor is a very useful index to determine well-being or relative fatness of an organism and the status of the aquatic ecosystem (Le- Cren, 1951). However, published information is not available till date on length weight relationship of sea-cucumber species from coastal waters around North-east region of Sri Lanka. Therefore, the present study was carried out to describe the length-weight relationship of four species $H$. atra, B. marmorata, S. naso and H. spinifera in North-east region of Sri Lanka.

\section{MATERIALS AND METHODS}

\section{Sample collection}

Random samples of sea-cucumbers were collected monthly from the commercial catches between May 2014 to September 2016 in main landing sites at Point Pedro and Mullaitivu in North-east region of Sri Lanka. External morphology of collected sea-cucumbers are shown in (Figure 1).

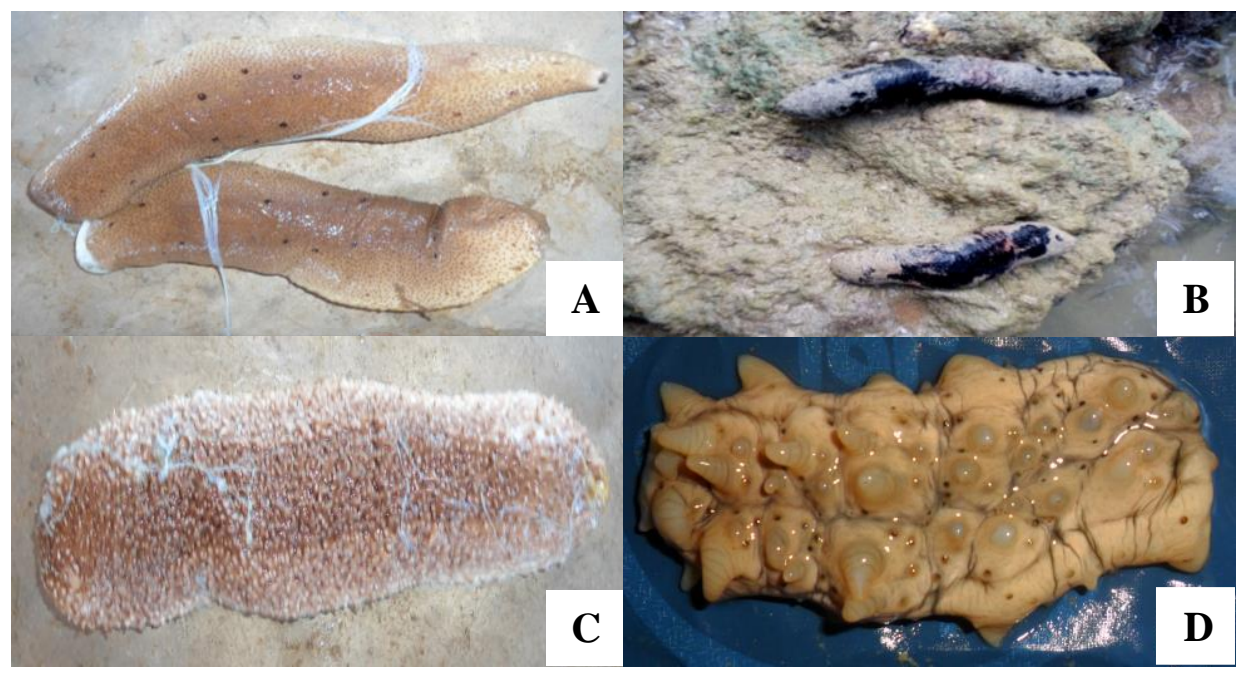

Figure 1. External morphology of (A) Bohadschia marmorata, (B) Holothuria atra, (C) Holothuria spinifera, (D) Stichopus naso

\section{Determination of Length-weight}

Samples were allowed to drain for 2 minutes before being weighed. All collected seacucumbers were individually weighed and measured to determine length-weight relationship. Length was measured to the nearest $0.5 \mathrm{~cm}$ using flexible tapes as the distance between the mouth and the anus, while weight was taken to the nearest $1 \mathrm{~g}$ with a spring scale. Lengthweight relationship was estimated using the power function (Eq. 01) according to (Pauly, 1983) 


$$
\mathrm{W}=\mathrm{a} \mathrm{L}^{\mathrm{b}}
$$

Where, $\mathrm{W}=$ Weight in $\mathrm{g}, \mathrm{L}=$ Length in $\mathrm{cm}, \mathrm{a}=$ Intercept, $\mathrm{b}=$ Slope

The values for $a$ and $b$ were calculated from the log transformed values of length and weight, i.e. $\log \mathrm{W}=\log \mathrm{a}+\mathrm{b} \log \mathrm{L}$, by least squares regression method. The coefficient of determination $\left(\mathrm{R}^{2}\right)$ that is the degree of relation between the length and weight was computed by the linear regression analysis: $R=r^{2}$.

Fulton's condition factor (K) was analyzed according to (Pauly, 1983) using the (Eq. 02)

$$
\mathrm{K}=100 \mathrm{~W} / \mathrm{L}^{3}
$$

Where, $\mathrm{K}=$ Condition factor, $\mathrm{W}=$ weight in $\mathrm{g}, \mathrm{L}=$ Length in $\mathrm{cm}$

\section{Data analysis}

The $b$-value for each species was tested by Student $t$-test to find out whether the $b$ values are significantly different from the predictions for isometric growth $(b=3)$, using Eq. 03.

$$
[\mathrm{t}=\mathrm{b}-3 / \mathrm{Sb}] \text {. }
$$

Where, $b=$ Regression coefficient, $\mathrm{Sb}=$ Standard error of ' $b$ '

Microsoft excel data analysis program was used for data analysis Thomas et al. (2003).

\section{RESULTS AND DISCUSSION}

Size distribution of sea-cucumbers in term of length and weight in North-east coastal waters of Sri Lanka indicated that $S$. naso has the minimum length and weight, while B. marmorata exhibited the maximum size (Table 1).

Table 1. Size distribution of sea-cucumbers in north-east coastal region of Sri Lanka

\begin{tabular}{lcccccc}
\hline Species & \multicolumn{2}{c}{ Length (cm) } & Mean \pm & \multicolumn{2}{c}{$\begin{array}{c}\text { Weight } \\
\text { (g) }\end{array}$} & Mean \pm STD \\
& Min & Max & STD & Min & Max & \\
\hline Holothuria spinifera & 14 & 22 & $19.5 \pm 2.16$ & 115 & 411 & $286 \pm 76.23$ \\
Bohadschia marmorata & 17 & 34 & $22 \pm 4.65$ & 280 & 831 & $516 \pm 160.26$ \\
Stichopus naso & 11 & 25 & $18 \pm 3.19$ & 136 & 345 & $194 \pm 52.35$ \\
Holothuria atra & 14 & 32 & $23 \pm 5.33$ & 126 & 732 & $245 \pm 122.63$ \\
\hline
\end{tabular}

Length and weight ranges of $B$. marmorata and $H$. atra in North-east region reported were found to be lower than the respective values of both species found in North-west coastal region of Sri Lanka as reported by (Dissanayaka and Wijeyaratne, 2007) indicating that overall conditions in North-west are better than that in North-east region. Mean length and weight of $H$. atra recorded in East cost of Sri Lanka were $23.3 \pm 1.3 \mathrm{~cm}$ and $111 \pm 6, \mathrm{~g}$ respectively (Dissanayaka and Stefansson, 2010). Reasons for deviations of these 
observations have to be investigated. However, length and weight data of $H$. spinifera and $S$. naso were not available in order to compare their present status. The parabolic relationship between length and weight of four sea cucumber species in North-east coastal waters are given in Figures. 2, 3, 4 and 5.

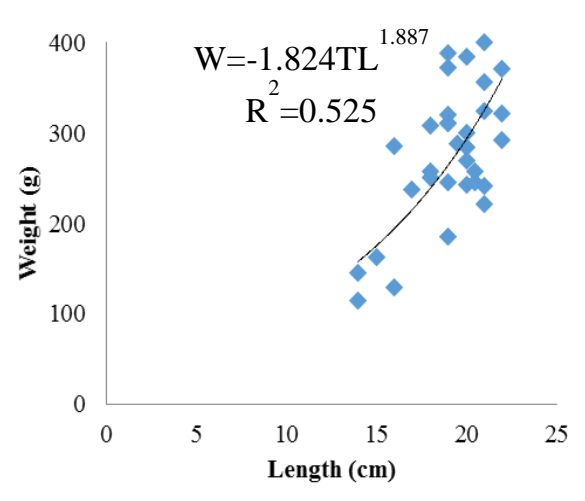

Fig 2. Parabolic relationship between length (cm) and weight $(\mathrm{g})$ of H. spinifera.

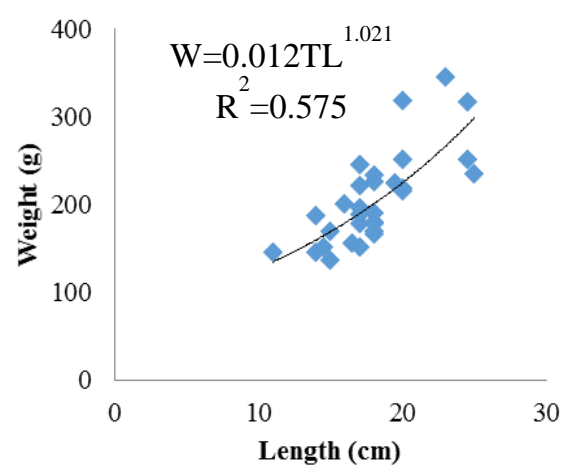

Fig 4. Parabolic relationship between length $(\mathrm{cm})$ and weight (g) of $S$. naso

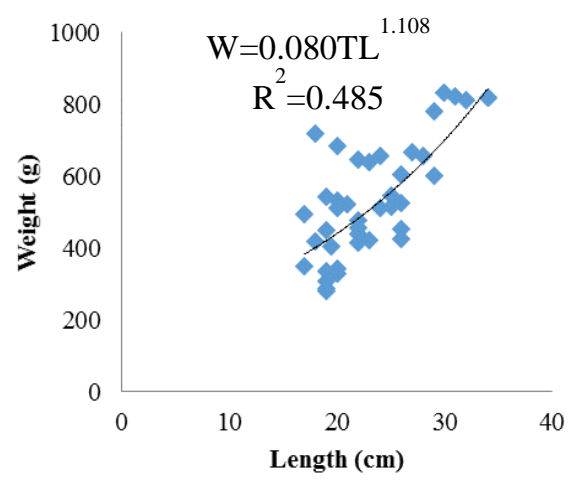

Fig 3. Parabolic relationship between length (cm) and weight (g) of B. marmorata.

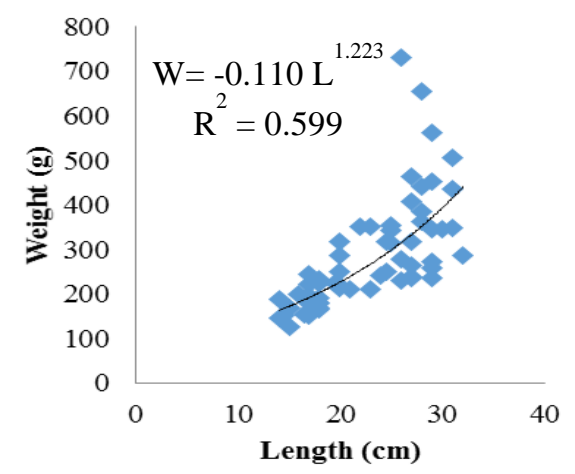

Fig 5. Parabolic relationship between length (cm) and weight (g) of $H$. atr

The length-weight relationship, regression parameters and condition factor for four seacucumber species are given in Table 2 .

Table 2. Length-weight relationship, regression parameters and condition factor

(K) of four sea-cucumber species collected from North-east coastal region of Sri Lanka

\begin{tabular}{lccccccc}
\hline Species & $\begin{array}{l}\text { Length-Weight } \\
\text { relationship }\end{array}$ & $\begin{array}{l}\text { Logarithmic } \\
\text { transformation }\end{array}$ & $\mathbf{n}$ & $\begin{array}{c}\mathbf{r} \\
\left(\mathbf{R}^{\mathbf{2}}\right)\end{array}$ & $\mathbf{a}$ & $\mathbf{b}$ & $\begin{array}{l}\text { Mean K } \pm \\
\text { STD }\end{array}$ \\
\hline H. spinifera & $\mathrm{W}=-1.824 \mathrm{~L}^{1.887}$ & $\mathrm{y}=1.887 \mathrm{x}+0.015$ & 67 & 0.725 & -1.824 & 1.887 & $3.898 \pm 1.03$ \\
B. marmorata & $\mathrm{W}=0.080 \mathrm{~L}^{1.108}$ & $\mathrm{y}=1.108 \mathrm{x}+1.203$ & 83 & 0.696 & 0.080 & 1.108 & $4.125 \pm 2.21$ \\
S. naso & $\mathrm{W}=0.012 \mathrm{~L}^{1.021}$ & $\mathrm{y}=1.021 \mathrm{x}+1.027$ & 61 & 0.758 & 0.012 & 1.021 & $3.558 \pm 1.73$ \\
H. atra & $\mathrm{W}=-0.110 \mathrm{~L}^{1.234}$ & $\mathrm{y}=1.223 \mathrm{x}+0.777$ & 62 & 0.774 & -0.110 & 1.223 & $2.688 \pm 1.31$ \\
\hline
\end{tabular}


Correlation coefficient (r) for length-weight relationship ranged from 0.696 to 0.774 (Table 2) and showed highly significant relationship between length and weight of collected sea cucumber species. Furthermore, Figures 2, 3, 4 and 5 showed coefficient of determination $\left(\mathrm{R}^{2}\right)$, which described contribution of independent variable to dependent variable, indicating that the contribution of length to weight for B. marmorata, H. spinifera, S. naso and H. atra were $48.5 \%, 52.5 \%, 57.5 \%$ and $59.9 \%$, respectively.

Analysis of length-weight relationship of $H$. spinifera, B. marmorata, S. naso and H. atra (Table 2) showed that the respective values of $b$ were 1.887, 1.108, 1.021 and 1.223, which were significantly $(P<0.05)$ lower than the regression coefficient of 3 . Pauly $(1983)$ revealed that the regression coefficient $b$ in length-weight relationship of marine organisms is usually 3. If $b=3$, growth is isometric where length increment is proportionate to weight increment. If it is greater than 3, the growth is positive allometric and if it is lower than 3, the marine organism exhibits negative allometric growth. Thus, in the present study the $b$ values were less than 3 indicating negative allometric growth, where length increment is greater than weight increment (Table 2). Most of the sea-cucumber species have elongated bodies in North-east coastal waters in Sri Lanka. Negative allometric growth of $H$. spinifera, $B$. marmorata, and $H$. atra are also reported by (Venkataraman, 2007) in Gulf of Mannar, India. However, the value of $\mathrm{b}$ in length-weight relationship of species could vary according to their locality and fishing season (Medina-Reyha, 2001; Prasad, 2001).

Condition factor is used to compare the well being of an organism and the health of the environment (Pauly, 1983). The mean condition factor (K) for H. spinifera, B. marmorata, $S$. naso and $H$. atra ranged between $2.688 \pm 1.34$ and $4.125 \pm 2.21$ (Table 2), Indicating that all sea-cucumber species were in good physical condition

\section{CONCLUSIONS}

The four sea cucumber species studied H. spinifera, B. marmorata, S. naso and H. atra in North-east coastal waters of Sri Lanka showed strong length-weight relationship and negative allmetric growth pattern. The North-east coastal water region provides healthy environment for sea-cucumber growth. The present study has provided baseline information on length-weight relationship and condition factor for sustainable management of seacucumber resources. A detailed study on spatial difference of length-weight relationship of male and female sea-cucumbers and monthly variation of condition factor is needed for better fisheries management.

\section{REFERENCES}

Beyer, J.E. (1987). On length-weight relationship computing the mean weight of the fish of a given length class. Fish bytes. 5(10), 11-13.

Clark, A.M. and Rowe, F.E.W. (1971). Monograph of shallow-water Indo-West Pacific echinoderms. Trustees of the British Museum. pp. 71-210.

Dissanayake, D.C.T. and Wijeyaratne, M. J. S. (2007). Studies on sea cucumber fishery in the North Western coastal region of Sri Lanka. Sri Lanka J. Aquat. Sci. 12, 19-38. 
Dissanayake, D.C.T. and Stefansson, G. (2010). Abundance and distribution of commercial sea cucumber species in the coastal waters of Sri Lanka. Aquat. Living Resour. 23, 303-313.

Garcia, C.B., Buarte, J.O., Sandoval, N., Von Schiller, D., Mello. and Najavas, P. (1989). Length-weight relationships of demersal fishes from the Gulf of Salamanca, Colombia. Fishbyte. 21, 30 - 32 .

Haimovici, M. and Velasco, G. (2000). Length-weight relationship of marine fishes from southern Brazil. NAGA, ICLARM Quarterly. 23(1), 14-16.

Le-Cren, E.D. (1951). The length-weight relationship and seasonal cycle in gonad weight and condition in the perch (Perca fluviatilis). J. Anim. Ecol. 20, 201-219.

Medina-Reyha, C.E. (2001). Growth and emigration of white shrimp, Litopenaeus vennamei in the Mar Muerto Lagoon, Southern Mexico. NAGA, ICLARM Quarterly. 24(1-2), 30-34.

Pauly, D. (1983). Some simple methods for the assessment of tropical fish stocks. FAO Fish. Tech. Pap. (234), 52.

Prasad, G. (2001). Length-weight relationship of Penaeus monodon reared in semi-intensive culture systems of Kerala, India. NAGA, ICLARM Q. 24(1-2):16-17.

Thomas, J., Venus, S. and Kurup B.M. (2003). Length-weight relationship of some deep sea fishes inhabiting the continental slope beyond $250 \mathrm{~m}$ depth along west coast of India. NAGA. ICLARM. Quarterly. 26, 17-21.

Veronika, K., Edrisinghe, U., Sivashanthini, S. and Athauda, A.R.S.B. (2016). Abundance and diversity of sea cucumbers in Point Pedro coastal waters in Jaffna peninsula of Sri Lanka. Trop. Agric. Res. 27(2), 182-189.

Veronika, K., Edrisinghe, U., Sivashanthini, S. and Athauda, A.R.S.B. (2017). Present status of holothurian fisheries in Mullaitivu coastal waters in North-east region of Sri Lanka. Trop. Agric. Res. 28(3), 216-222.

Venkataraman, C. (2007). Present status of population of holothurians in India. FAOBOBLME. pp. 58 